University of New Hampshire

University of New Hampshire Scholars' Repository

Faculty Publications

$1-8-2009$

\title{
Are biogenic emissions a significant source of summertime atmospheric toluene in the rural Northeastern United States?
}

\author{
Marguerite L. White \\ University of New Hampshire, Durham \\ Rachel S. Russo \\ University of New Hampshire, Durham \\ Yong Zhou \\ University of New Hampshire, Durham \\ Jesse L. Ambrose \\ University of New Hampshire, Durham \\ Karl B. Haase \\ University of New Hampshire, Durham
}

See next page for additional authors

Follow this and additional works at: https://scholars.unh.edu/faculty_pubs

Comments

This is an article published by European Geosciences Union in Atmospheric Chemistry and Physics in 2009, available online: https://dx.doi.org/10.5194/acp-9-81-2009

\section{Recommended Citation}

White, M.L., ${ }^{\circ}$ R. S. Russo, Y. Zhou, J. Ambrose, ${ }^{\circ}$ K. Hasse, E. Frinak, R.K. Varner, O.W. Wingenter, H. Mao, R. Talbot, and B.C. Sive (2009), Are Biogenic Emissions a Significant Source in Summertime Toluene Enhancements in the Rural Northeast?, Atmos. Chem. Phys. Discuss., 9, 1, 81-92.

This Article is brought to you for free and open access by University of New Hampshire Scholars' Repository. It has been accepted for inclusion in Faculty Publications by an authorized administrator of University of New Hampshire Scholars' Repository. For more information, please contact Scholarly.Communication@unh.edu. 


\section{Authors}

Marguerite L. White, Rachel S. Russo, Yong Zhou, Jesse L. Ambrose, Karl B. Haase, E. K. Frinak, Ruth K. Varner, Oliver W. Wingenter, Huiting Mao, Robert W. Talbot, and Barkley C. Sive 


\title{
Are biogenic emissions a significant source of summertime atmospheric toluene in the rural Northeastern United States?
}

\author{
M. L. White ${ }^{1}$, R. S. Russo ${ }^{1}$, Y. Zhou ${ }^{1}$, J. L. Ambrose ${ }^{1,2}$, K. Haase ${ }^{1,2}$, E. K. Frinak ${ }^{1}$, R. K. Varner ${ }^{1}$, O. W. Wingenter ${ }^{3}$, \\ H. Mao ${ }^{1}$, R. Talbot ${ }^{1}$, and B. C. Sive ${ }^{1}$ \\ ${ }^{1}$ Climate Change Research Center, Institute for the Study of Earth, Oceans, and Space, University of New Hampshire, \\ Durham, NH 03824, USA \\ ${ }^{2}$ Department of Chemistry, University of New Hampshire, Durham, NH 03824, USA \\ ${ }^{3}$ Department of Chemistry, New Mexico Institute of Mining and Technology, Socorro, NM 87801, USA
}

Received: 23 April 2008 - Published in Atmos. Chem. Phys. Discuss.: 24 June 2008

Revised: 5 December 2008 - Accepted: 5 December 2008 - Published: 8 January 2009

\begin{abstract}
Summertime atmospheric toluene enhancements at Thompson Farm in the rural northeastern United States were unexpected and resulted in a toluene/benzene seasonal pattern that was distinctly different from that of other anthropogenic volatile organic compounds. Consequently, three hydrocarbon sources were investigated for potential contributions to the enhancements during 2004-2006. These included: (1) increased warm season fuel evaporation coupled with changes in reformulated gasoline (RFG) content to meet US EPA summertime volatility standards, (2) local industrial emissions and (3) local vegetative emissions. The contribution of fuel evaporation emission to summer toluene mixing ratios was estimated to range from 16 to $30 \mathrm{pptv} \mathrm{d}^{-1}$, and did not fully account for the observed enhancements (2050 pptv) in 2004-2006. Static chamber measurements of alfalfa, a crop at Thompson Farm, and dynamic branch enclosure measurements of loblolly pine trees in North Carolina suggested vegetative emissions of 5 and $12 \mathrm{pptv} \mathrm{d}^{-1}$ for crops and coniferous trees, respectively. Toluene emission rates from alfalfa are potentially much larger as these plants were only sampled at the end of the growing season. Measured biogenic fluxes were on the same order of magnitude as the influence from gasoline evaporation and industrial sources (regional industrial emissions estimated at $7 \mathrm{pptv} \mathrm{d}^{-1}$ ) and indicated that local vegetative emissions make a significant contribution to summertime toluene enhancements. Additional studies are needed to characterize the variability and factors controlling toluene emissions from alfalfa and other vegetation types throughout the growing season.
\end{abstract}

Correspondence to: M. L. White (mwhite@gust.sr.unh.edu)

\section{Introduction}

Toluene is a ubiquitous aromatic volatile organic compound (VOC) in the troposphere (Dewulf and Van Langenhove, 1997; Singh et al., 1985) that has been classified by the United States Environmental Protection Agency (US EPA) as an air toxic for its detrimental effects on human central nervous system function with acute exposure (Goldhaber et al., 1995). Its oxidation in the presence of nitrogen oxides $\left(\mathrm{NO}_{\mathrm{x}}\right)$ can lead to tropospheric ozone $\left(\mathrm{O}_{3}\right)$ formation, a secondary pollutant and respiratory irritant (Wang et al., 1998). Low volatility oxidation products can also partition into particulate matter becoming a significant component of fine aerosol mass (Schauer et al., 2002). Of particular importance to air quality in rural environments, recent studies indicate that secondary organic aerosol (SOA) formation from aromatic precursors, including toluene, is substantially faster under low $\mathrm{NO}_{\mathrm{x}}$ conditions than under high $\mathrm{NO}_{\mathrm{x}}$ conditions ( $\mathrm{Ng}$ et al., 2007).

Toluene sources are understood to be primarily anthropogenic and include combustion, fuel evaporation, solvent usage, and industrial processes (Singh and Zimmerman, 1992). It is often assumed that these sources are concentrated in urban areas and have emission rates that are consistently proportional to benzene, another widely distributed aromatic VOC and air toxic with similar anthropogenic sources. These assumptions, along with several others regarding sinks and air mass mixing, allow the use of toluene/benzene ratios in characterizing air mass photochemical age at non-urban locations (e.g. Warneke et al., 2007; deGouw et al., 2005; Gelencser et al., 1997).

However, the discovery of elevated warm season toluene mixing ratios at a rural site in northern New England brings these assumptions into question. In the long-term data set of

Published by Copernicus Publications on behalf of the European Geosciences Union. 
daily VOC measurements made at Thompson Farm in coastal New Hampshire, toluene followed a significantly different seasonal pattern than benzene and other common anthropogenic tracers which usually reached their minimum levels during summer. The presence of elevated toluene mixing ratios from late spring to early fall at this rural location, even in well-processed air masses, could reflect several influences including a seasonal cycle in urban anthropogenic emissions of toluene and/or an unidentified local warm season source.

Any seasonal cycle in urban anthropogenic toluene emissions most likely reflects changes in reformulated gasoline (RFG) hydrocarbon content to meet US EPA mandated VOC volatility requirements from 1 June to 15 September of each year (Romanow, 2008). To fulfill both these lower fuel Reid Vapor Pressure (RVP) requirements and fuel octane grades in summer, refineries often replace more volatile high octane compounds such as n-butane with heavier alkanes and aromatic compounds in their gasoline formulations (Gary and Handwerk, 2001; Lough et al., 2005). An analysis of individual hydrocarbon compound content in 2000-2001 summer and winter RFG samples from Milwaukee, Wisconsin, indicated that toluene exhibited the largest summertime increase of all hydrocarbons increasing from 1\% (weight) of fuel in winter to approximately $10 \%$ in summer (Lough et al., 2005). While tunnel studies in the Milwaukee area indicated that these changes in fuel content did not significantly alter toluene emissions or toluene-to-benzene ratios from mobile source exhaust, they did affect the percent hydrocarbon composition of fuel headspace vapors with toluene, i-pentane, and 2,2,4-trimethylpentane exhibiting the largest percent increase for summertime fuels (Lough et al., 2005). The effect these seasonal gasoline content changes could have on fuel evaporation sources suggests a distinct yearly cycle in urban toluene emissions which must be considered in evaluating seasonal toluene variability in New England.

Local plants may also be seasonal toluene sources with particular significance in extensively vegetated rural areas such as northern New England. In a series of laboratory enclosure experiments, Heiden et al. (1999) showed that isotopically labeled ${ }^{13} \mathrm{CO}_{2}$ taken up by sunflowers was emitted as ${ }^{13} \mathrm{C}$ labeled toluene. In the same study, a combination of laboratory and field experiments indicated that toluene emission rates for sunflowers and pine trees increased with plant stress (i.e., pathogen attack, low nutrients, leaf wounding). Considering the significant influence regional biogenic VOC emissions have on tropospheric chemistry in coastal New England (Griffin et al., 2004; Mao et al., 2006; White et al., 2008), the potential contribution of vegetative toluene emissions in seasonal toluene enhancements at Thompson Farm warrants exploration.

Elevated toluene mixing ratios at rural locations have also been previously attributed to local industrial emissions. VOC measurements made as part of the Southern Oxidants Study in June 1995 revealed significant toluene enhancements at New Hendersonville, Tennessee, which correlated strongly with winds coming from the direction of a regional toluene emitting industrial facility (McClenny et al., 1998). Such observations highlight the impact that local anthropogenic sources can have on ambient toluene variability in rural locations.

In this paper we examine all three sources in more detail for their potential relative contribution to the summer toluene enhancements observed at Thompson Farm. In particular, we identify and quantify the contribution of seasonal changes in gasoline formulation to evaporative toluene emissions. We also present estimates of toluene emissions from alfalfa crops in New Hampshire and loblolly pine trees in North Carolina. Finally, we evaluate the impact of annual reported industrial releases of toluene in the local area around Thompson Farm.

\section{Methods}

Measurements from several studies were utilized in this paper, and a brief description of each follows. All data is presented in local time (LT) which is UTC-04:00 during daylight savings time and UTC-05:00 during the rest of the year. Seasons are defined as follows: winter is December-February, spring is March-May, summer is June-August, and autumn is September-November.

\subsection{Thompson farm ambient VOC measurements}

Situated $25 \mathrm{~km}$ from the Gulf of Maine in rural Durham, NH, USA, the University of New Hampshire AIRMAP observation site at Thompson Farm $\left(43.11^{\circ} \mathrm{N}, 70.95^{\circ} \mathrm{W}, 24 \mathrm{~m}\right.$ above sea level, a.s.l) is established on an active corn and alfalfa farm surrounded by mixed forest. Daily canister samples have been collected from 12 January 2004 to 31 May 2007 from the top of the $12 \mathrm{~m}$ sampling tower and provide the most continuous record of interseasonal and interannual VOC variability for the site. Sample collection times ranged from 08:30 to 19:30 LT daily, with the majority of samples in all seasons obtained between 12:00 and 15:00. The air samples were collected in evacuated 2 L electropolished stainless steel canisters and analyzed at the University of New Hampshire on a three GC system equipped with two flame ionization detectors (FIDs), two electron capture detectors (ECDs), and a mass spectrometer (MS) for $\mathrm{C}_{2}-\mathrm{C}_{10}$ nonmethane hydrocarbons (NMHCs), $\mathrm{C}_{1}-\mathrm{C}_{2}$ halocarbons and $\mathrm{C}_{1}-\mathrm{C}_{5}$ alkyl nitrates (Sive et al., 2005; Zhou et al., 2005; Zhou et al., 2008).

All data from samples in the 90th percentile for ethyne $\left(\mathrm{C}_{2} \mathrm{H}_{2}\right)$, nitrogen oxide (NO), total pentanes (i-pentane and n-pentane, and total butanes (i-butane and n-butane) for each season (winter, spring, summer, autumn) were excluded from the analyzed dataset to provide a representative picture of background mixing ratios independent of strong local vehicle exhaust and fuel evaporative influence. Data from samples with acetonitrile levels $\geq 150$ pptv were also excluded to 
eliminate strong biomass burning influences (Lobert et al., 1990; Warneke et al., 2006). In total, both these exclusions affected approximately $25 \%$ of the dataset. While $\mathrm{C}_{2} \mathrm{H}_{2}$, butanes and pentanes were measured as part of the VOC analysis described above, NO was measured at the Thompson Farm observation tower using a chemiluminescent technique described by Mao and Talbot (2004a) and acetonitrile measurements were made using proton transfer reactionmass spectrometry (PTR-MS) (Talbot et al., 2005). Mean monoterpene mixing ratios from summer 2004-2006 and correlations between monoterpenes and toluene in 2006 were also calculated from PTR-MS measurements. Additionally, carbon monoxide (CO), used to calculate $\mathrm{C}_{2} \mathrm{H}_{2} / \mathrm{CO}$ ratios, was measured using infrared spectroscopy as described by Mao and Talbot (2004a). All mean measurements are presented as mean \pm standard error where the standard error of the mean was calculated as described by Taylor (1982).

\subsection{Thompson farm vegetative flux measurements}

Net toluene flux from alfalfa (Medicago sativa) was measured at Thompson Farm with a static chamber made of Lexan with an aluminum frame $(61 \mathrm{~cm} \times 61 \mathrm{~cm} \times 46 \mathrm{~cm})$ (Varner et al., 1999). Blank chamber tests conducted over a 10 year old concrete pad and a dirt road/bare soil indicated no VOC emission artifacts associated with the apparatus. During flux measurements, the chamber was set on an aluminum collar $(61 \mathrm{~cm} \times 61 \mathrm{~cm})$ placed in an alfalfa covered plot below the AIRMAP observation tower a week before sampling. An ambient air sample was taken directly above the collar immediately prior to sampling by opening an evacuated $2 \mathrm{~L}$ electropolished stainless steel canister. The chamber was then placed into the collar lip and sealed with water. Three headspace samples were collected every $6 \mathrm{~min}$ in $2 \mathrm{~L}$ electropolished stainless steel canisters.

The collar was sampled twice on 25 September 2007. For the first flux measurement (before harvest), the vegetation within the chamber was intact. The chamber was then removed and the vegetation in the collar was clipped to within 2 inches of the ground. The harvested vegetation was left lying within the collar during the second flux measurement (after harvest) which was taken approximately 2 min later. The same collar was sampled again without disturbing vegetation re-growth on 5 October 2007. All collar measurements on 25 September and 5 October were made between 13:30 and 15:30 LT. Net fluxes $\left(\mathrm{nmol} \mathrm{m}^{-2} \mathrm{~d}^{-1}\right)$ were calculated as follows:

Flux $=\frac{d C}{d t} \times \frac{V_{c}}{A_{c}}$

where $\frac{d C}{d t}$ is the linear regression slope of the chamber headspace concentration (in $\mathrm{nmol} \mathrm{m}^{-3}$ ) versus time (d), $V_{c}$ is the chamber volume $\left(\mathrm{m}^{3}\right)$, and $A_{c}$ is the collar area $\left(\mathrm{m}^{2}\right)$. Flux errors were propagated as described by Taylor (1982) from the standard error of the linear regression slope and the estimated upper limit of uncertainty in the chamber volume $(2 \%)$ and collar area $(2 \%)$.

\subsection{Duke forest vegetative flux measurements}

In June 2005, VOC fluxes were measured from loblolly pine (Pinus taeda) and sweetgum (Liquidambar styraciflua) trees at the Duke Forest Free Atmospheric Carbon Enrichment (FACE) site $\left(35^{\circ} 52^{\prime} \mathrm{N}, 79^{\circ} 59^{\prime} \mathrm{W}, 163 \mathrm{~m}\right.$ a.s.l. $)$ located in Chapel Hill in the central Piedmont region of North Carolina, USA (Sive et al., 2007). Flux measurements were collected every two hours over two 48-h sampling periods using dynamic branch enclosures made of large (36L) clear Teflon bags supported by an external frame. A single branch from the tree sampled was carefully placed within the enclosure and exposed to a continuous flow of air from the canopy for 24 to $48 \mathrm{~h}$ prior to sampling. A mass flow meter monitored the rate of air flow into the bag $\left(3-6 \mathrm{~L} \mathrm{~min}^{-1}\right)$ while a cold palladium catalyst was used for $\mathrm{O}_{3}$ removal. Subsamples of air from the enclosure inlet and outlet were collected during each flux measurement and pressurized to $35 \mathrm{psig}$ in $2 \mathrm{~L}$ electropolished stainless steel canisters. Canisters were then returned to UNH for analysis on the three GC system.

Vegetation fluxes $\left(\mathrm{nmol} \mathrm{m}^{-2} \mathrm{LA} \mathrm{d}^{-1}\right)$ were calculated as follows:

Flux $=\left[\mathrm{C}_{\mathrm{B}}-\mathrm{C}_{\mathrm{PC}}\right] \times$ flow $\times \mathrm{LA}^{-1}$

where $\mathrm{C}$ is the number density in $\mathrm{nmol} \mathrm{m}^{-3}$ of toluene in both the bag (B) and post-catalyst (PC) air samples, flow is the rate of air flow into the bag in $\mathrm{m}^{3} \mathrm{~d}^{-1}$, and LA represents the leaf area $\left(\mathrm{m}^{2}\right)$ of the branch enclosed. All loblolly pine fluxes presented in this paper were converted to $\mathrm{nmol} \mathrm{m}^{-2}$ ground area $\mathrm{d}^{-1}$ by multiplying by the Ring 1 leaf area index (LAI) at the Duke Forest sampling site for June 2005 (7 $\mathrm{m}^{2} \mathrm{LA} \mathrm{m}^{-2}$ ground area) (FACTS-1, 2006). Flux errors were propagated as described by Taylor (1982) from the upper limit of measurement uncertainties for toluene (5\%), leaf area $(10 \%)$, and LAI (40\%), and the standard error of the mean inlet flow rate during measurement. While measurements were made in both ambient and elevated (+200 ppmv) $\mathrm{CO}_{2}$ environments, only the ambient measurements are reported for clarity. There was no significant difference in toluene fluxes measured in the two $\mathrm{CO}_{2}$ regimes.

\section{Warm season toluene enhancements at Thompson Farm}

The time series data for benzene and toluene, presented in Fig. 1 with 15 day moving averages, were constructed from the daily canister samples at Thompson Farm collected during 2004-2007 and filtered as described in the methods section. There was a distinct seasonal trend in benzene over the three year period with elevated mixing ratios in winter (Table 1; 140 \pm 2 pptv, 2004-2006 mean) most likely reflecting a 


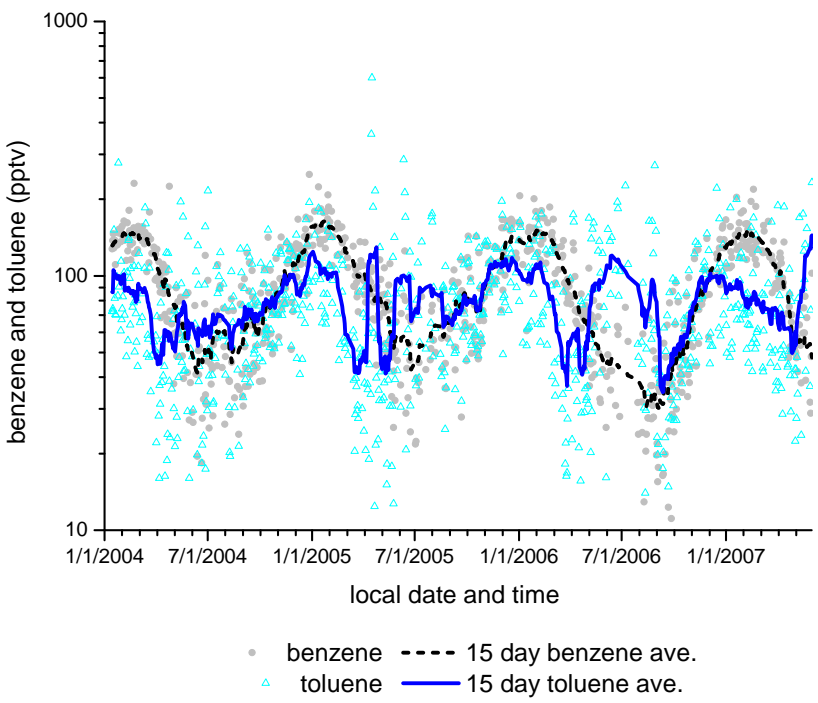

Fig. 1. Benzene and toluene mixing ratios from daily canister measurements made 12 January 2004 to 31 May 2007. The 15 day moving averages of the individual measurements are displayed on the graph as solid and dashed lines.

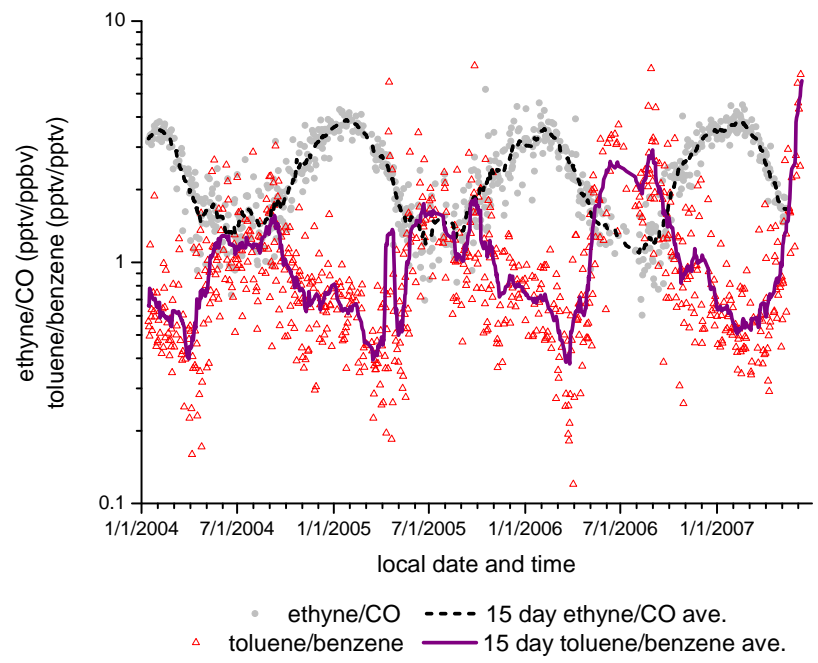

Fig. 2. A comparison of $\mathrm{C}_{2} \mathrm{H}_{2} / \mathrm{CO}$ and toluene/benzene ratios as tracers of urban anthropogenic influence from the Thompson Farm daily canisters from 12 January 2004 through 31 May 2007. The 15 day moving averages of the daily ratios are displayed on the graph as solid and dashed lines.

combination of factors including less oxidation by hydroxyl radical $(\mathrm{OH})$, seasonally reduced boundary layer heights, and increased emissions from wintertime combustion processes (Singh and Zimmerman, 1992; Cheng et al., 1997; Na and Kim, 2001). As OH levels and boundary layer heights increased in the spring, benzene mixing ratios decreased to a mean of $85 \pm 2$ pptv (2004-2006). Minimum benzene values were observed in the summer months for all three years
Table 1. The seasonal mean mixing ratios \pm standard errors for benzene, toluene, and the toluene/benzene ratio in the Thompson Farm daily cans from 12 January 2004 through 31 May 2006. The $n$ values in parentheses are the number of samples included in the seasonal mean for that year after filtering the data set. The superscripts $\mathrm{a}, \mathrm{b}$, and $\mathrm{c}$ indicate means within each season that are significantly different according to an independent means t-test, $p<0.05$, SPSS 15.0.1.1.

\begin{tabular}{llll}
\hline & \multicolumn{3}{c}{ Mean $( \pm$ st. err) } \\
Season and year & $\begin{array}{l}\text { benzene } \\
\text { tpptv) }\end{array}$ & $\begin{array}{l}\text { toluene } \\
\text { tpptv) }\end{array}$ & $\begin{array}{l}\text { tpluene/benzene } \\
\text { (pptv/pptv) }\end{array}$ \\
\hline winter & & & \\
$2004(n=36)$ & $143 \pm 4^{\mathrm{a}}$ & $89 \pm 7^{\mathrm{ab}}$ & $0.63 \pm 0.05^{\mathrm{a}}$ \\
$2004-5(n=57)$ & $144 \pm 5^{\mathrm{a}}$ & $97 \pm 5^{\mathrm{ab}}$ & $0.67 \pm 0.03^{\mathrm{ab}}$ \\
$2005-6(n=50)$ & $141 \pm 4^{\mathrm{a}}$ & $104 \pm 6^{\mathrm{b}}$ & $0.73 \pm 0.03^{\mathrm{b}}$ \\
$2006-7(n=60)$ & $133 \pm 4^{\mathrm{a}}$ & $88 \pm 5^{\mathrm{a}}$ & $0.66 \pm 0.04^{\mathrm{ab}}$ \\
& & & \\
spring & & & \\
$2004(n=66)$ & $92 \pm 5^{\mathrm{a}}$ & $64 \pm 5^{\mathrm{a}}$ & $0.75 \pm 0.06^{\mathrm{a}}$ \\
$2005(n=71)$ & $83 \pm 3^{\mathrm{a}}$ & $60 \pm 10^{\mathrm{a}}$ & $0.8 \pm 0.1^{\mathrm{a}}$ \\
$2006(n=65)$ & $81 \pm 4^{\mathrm{a}}$ & $64 \pm 5^{\mathrm{a}}$ & $0.86 \pm 0.08^{\mathrm{a}}$ \\
$2007(n=59)$ & $85 \pm 4^{\mathrm{a}}$ & $72 \pm 6^{\mathrm{a}}$ & $0.95 \pm 0.08^{\mathrm{a}}$ \\
& & & \\
summer & & & \\
$2004(n=56)$ & $51 \pm 3^{\mathrm{a}}$ & $63 \pm 5^{\mathrm{a}}$ & $1.23 \pm 0.07^{\mathrm{a}}$ \\
$2005(n=41)$ & $56 \pm 3^{\mathrm{a}}$ & $85 \pm 9^{\mathrm{b}}$ & $1.47 \pm 0.09^{\mathrm{b}}$ \\
$2006(n=35)$ & $38 \pm 3^{\mathrm{b}}$ & $100 \pm 10^{\mathrm{b}}$ & $2.5 \pm 0.2^{\mathrm{c}}$ \\
& & & \\
fall & & & \\
$2004(n=74)$ & $78 \pm 3^{\mathrm{a}}$ & $79 \pm 7^{\mathrm{a}}$ & $0.96 \pm 0.06^{\mathrm{a}}$ \\
$2005(n=63)$ & $83 \pm 4^{\mathrm{a}}$ & $100 \pm 10^{\mathrm{a}}$ & $1.2 \pm 0.1^{\mathrm{ab}}$ \\
$2006(n=64)$ & $61 \pm 4^{\mathrm{b}}$ & $80 \pm 8^{\mathrm{a}}$ & $1.4 \pm 0.1^{\mathrm{b}}$ \\
\hline & & &
\end{tabular}

(49 \pm 2 pptv, 2004-2006 mean) and they began increasing again in autumn (75 \pm 2 pptv, 2004-2006, mean).

Similarly, toluene mixing ratios were elevated during winter with a seasonal mean of $95 \pm 3$ pptv in all three years followed by a decrease to the springtime mean level of $56 \pm 4$ pptv (Fig. 1 and Table 1). However, toluene increased again beginning in April or May and remained elevated into September during all three years, with mean values of $85 \pm 5$ and $88 \pm 5$ pptv for summer and autumn, respectively.

It should be noted that each successive year exhibited summertime toluene enhancements, with 2006 levels reaching a maximum mean of $100 \pm 10 \mathrm{pptv}$ (Table 1). Subtracting the minimum toluene mixing ratios reached in April and May (42 \pm 3 pptv, 2004-2006 mean) from the daily summer means provides a rough estimate of the warm season enhancement levels $(21 \pm 6,43 \pm 9$, and $50 \pm 10 \mathrm{pptv}$ in 2004,2005 , and 2006, respectively).

These summertime toluene enhancements at Thompson Farm resulted in a toluene/benzene ratio seasonal pattern 


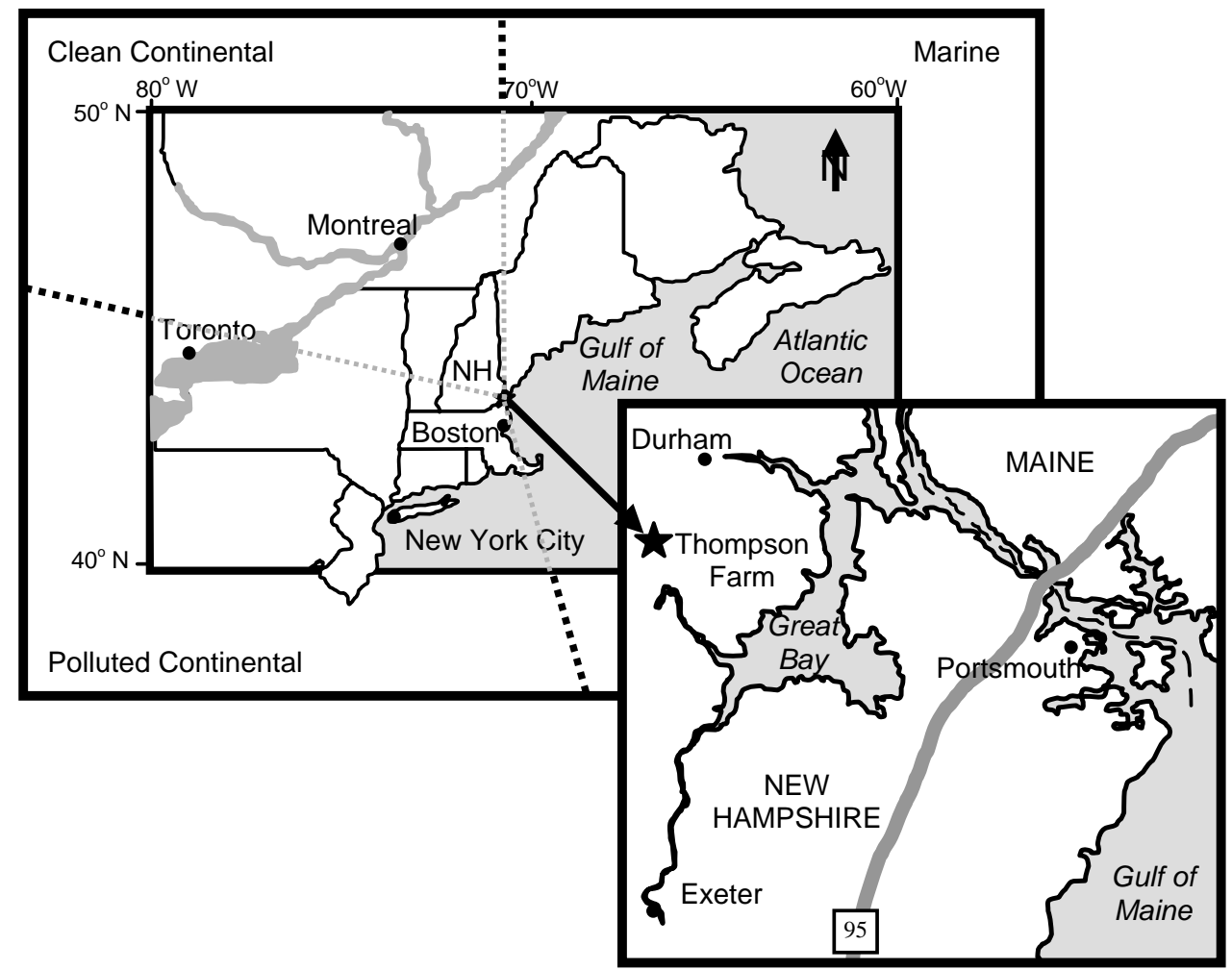

Fig. 3. A map of the air mass source regions influencing Thompson Farm.

distinctly different from that of other anthropogenic VOC relationships. For example, the daily canister toluene/benzene ratio and $\mathrm{C}_{2} \mathrm{H}_{2} / \mathrm{CO}$ ratio are compared in Fig. 2 over the three year study period. Combustion sources of $\mathrm{C}_{2} \mathrm{H}_{2}$ and $\mathrm{CO}$ are largely concentrated in urban areas making them useful tracers of anthropogenic influence, particularly when biomass burning influences are minimal (Lobert et al., 1990; Warneke et al., 2006).

$\mathrm{C}_{2} \mathrm{H}_{2}$ also has a significantly faster rate of reaction with $\mathrm{OH}$, its major sink, than $\mathrm{CO}$ making the ratio of the two compounds an indicator of air mass photochemical and mixing processes (Smyth et al., 1996). The $\mathrm{C}_{2} \mathrm{H}_{2} / \mathrm{CO}$ ratios observed at Thompson Farm reached their minimum values in summer reflecting higher levels of $\mathrm{OH}$ and increased air mass photochemical processing (Fig. 2). In contrast, the annual maximum toluene/benzene ratios at Thompson Farm occurred from June through September with the mean summer toluene-to-benzene ratio for all three years $(1.9 \pm 0.1)$ significantly higher than all other months sampled $(0.90 \pm 0.02$; independent means t-test: $p<0.001$, SPSS v.15.0.1.1). Summer 2006 had the highest toluene/benzene ratios of all three years with a maximum (6.4 on 28 August 2006) nearly a factor of two larger than the emission ratios derived in urban plumes sampled directly in New England during NEAQS $2002(3.7 \pm 0.3)$ (deGouw et al., 2005) and ICARTT 2004 (4.25) (Warneke et al., 2007).
A closer examination of the predominant source region impacting Thompson Farm during each season reveals that differences in air mass origin did not influence the summer toluene/benzene enhancements. Air mass source regions were classified as polluted continental, clean continental, and marine (Fig. 3) using $72 \mathrm{~h}$ back trajectories simulated using the NOAA HYSPLIT transport and dispersion model (Draxler and Rolph, 2003) for each daily sample collection time in the filtered data set.

During the summer months, the air masses sampled were relatively equally divided between the three different source regions with $37 \%$ coming from a clean continental area to the northwest, 33\% from marine influenced areas to the northeast and east, and 30\% from more polluted continental sources to the south and southwest. In contrast, the majority (54\%) of air masses sampled during the winter came from clean continental source region, $15 \%$ from the clean marine influenced area, and $31 \%$ from the polluted continental source region. However, this shift in source region between summer and winter did not seem to correlate with the seasonal variation of the toluene/benzene ratios. More specifically, elevated toluene/benzene ratios were measured in air masses from every source region during the summer months (mean summer toluene/benzene ratios \pm standard error by source region: polluted continental $=1.5 \pm 0.1$, clean continental $=1.9 \pm 0.2$, and marine $=2.0 \pm 0.4$ ). These summer ratios 


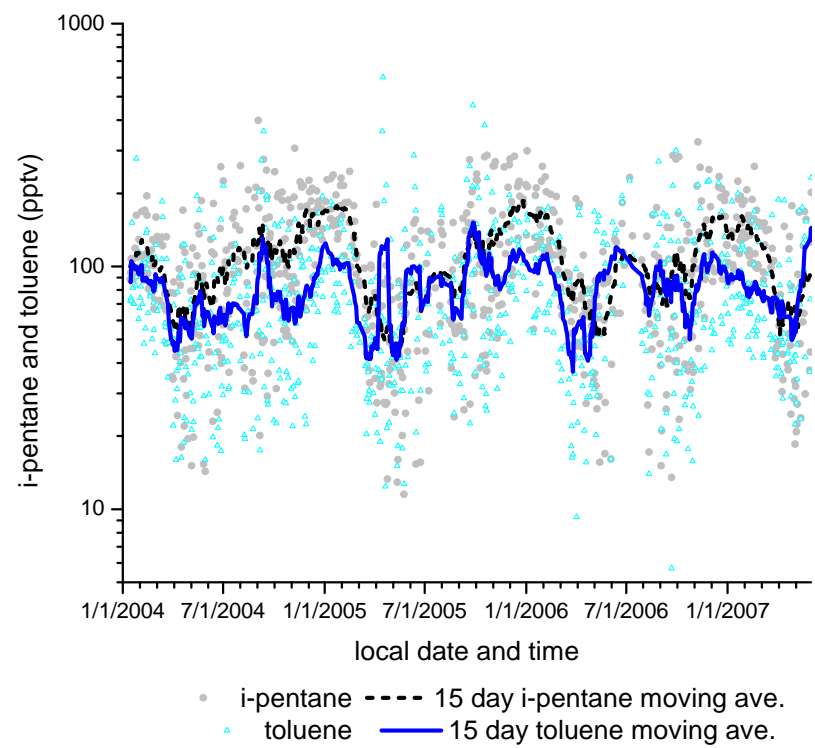

Fig. 4. A comparison of i-pentane and toluene mixing ratios from the Thompson Farm daily canisters from 12 January 2004 through 31 May 2007. The 15 day moving averages of the individual measurements are displayed on the graph as solid and dashed lines.

were at least twice the toluene/benzene ratios observed in air masses from all directions during the winter months (mean winter toluene/benzene ratios \pm standard error by source region: polluted continental $=0.73 \pm 0.05$, clean continental $=0.61 \pm 0.02$, and marine $=0.69 \pm 0.03$ ). Because the daily canister data set was also filtered to remove the influence of fresh fuel evaporation and combustion sources on toluene mixing ratios, these anomalously high summertime tolueneto-benzene ratios must reflect additional toluene source influences in all source regions.

\section{Evidence for various toluene source influences at Thompson Farm}

To better characterize the influence of local and/or regional sources on toluene levels at Thompson Farm, the effect of photochemically processed urban fuel evaporation emissions on the observed toluene variability must be identified and quantified. A strong contribution from gasoline evaporation to the warm season toluene enhancements was indicated by concurrent spring and summer increases in both i-pentane and toluene mixing ratios (Fig. 4). The two compounds reached their minimum levels in April or May of each year followed by similar increases with the approach of summer fuel volatility requirements on 1 June. However, a closer examination of the relationship between toluene and i-pentane from April to May revealed distinctly that the springtime increases in toluene were independent of those in i-pentane, particularly in 2005 and 2006. For example, beginning on
15 April 2005, ambient toluene at Thompson Farm was significantly elevated (up to $600 \mathrm{pptv}$ ) for several days while ipentane levels continued to decrease. This episode was relatively short-lived, and toluene reached its springtime minimum on 10 May 2005 before rising concurrently with ipentane. In contrast, springtime toluene increases in 2006 followed a different pattern with a springtime minimum on 28 April 2006 several weeks earlier than the i-pentane minimum on 13 May 2006. Such variability provides further support for the influence of another toluene source(s) in addition to fuel evaporation on seasonal enhancements at Thompson Farm.

The impact of these additional sources is also indicated in the scatter of the toluene/i-pentane correlation from June through August in 2004, 2005, and 2006 (Fig. 5). The implementation of summer fuel volatility requirements from 1 June to 15 September indicates that fuel evaporation emissions of toluene should have been at their greatest during this period. In Fig. 5, the background relationships between toluene and i-pentane were defined as the linear regression equations for daily canister data below the median values for i-pentane and toluene during each summer (2004-2006). The majority of the data in all years corresponded closely to the background relationship indicating that fuel evaporation was a major factor influencing summer toluene levels. In 2005 and 2006, there was also significant scatter with elevated toluene over a wide range of i-pentane levels (15-260 pptv). Elevated toluene mixing ratios were actually higher in 2005 (approximately 100-300 pptv) than in 2004 (50-200 pptv) despite a smaller range of i-pentane (15-150 pptv in summer 2005) further suggesting a strong influence from additional toluene sources besides fuel evaporation. Compared to 2004 and 2005, the background relationship of toluene and i-pentane in summer 2006 was less well-defined implying that fuel evaporation was not as dominant a source to seasonal toluene enhancements that year. A higher background slope $(0.7 \pm 0.2$ compared to $0.4 \pm 0.1$ and $0.5 \pm 0.2$ in 2004 and 2005, respectively) further implies input from an additional toluene source even in the cleanest air masses in 2006.

Potential toluene sources include the crop plants and coniferous trees surrounding Thompson Farm. Static enclosure flux measurements of alfalfa conducted at Thompson Farm in September 2007 revealed significant toluene emissions, particularly when the plants were harvested (Fig. 6 and Table 2). The alfalfa flux rates presented in Table 2 were calculated from the linear regression slopes shown in Fig. 6 as described in Sect. 2.2. Blank chamber tests made over a dirt road immediately prior to the alfalfa experiment showed that toluene increases were not chamber artifacts.

Furthermore, ambient air samples taken at the enclosure site increased from approximately $80 \mathrm{pptv}$ prior to harvest at 14:40 to over 400 pptv immediately after harvest at 15:10 indicating a significant release of toluene in the area. Since alfalfa was planted in the Thompson Farm fields in 2006, the vegetative emissions presented in Fig. 6 could help explain 
a)

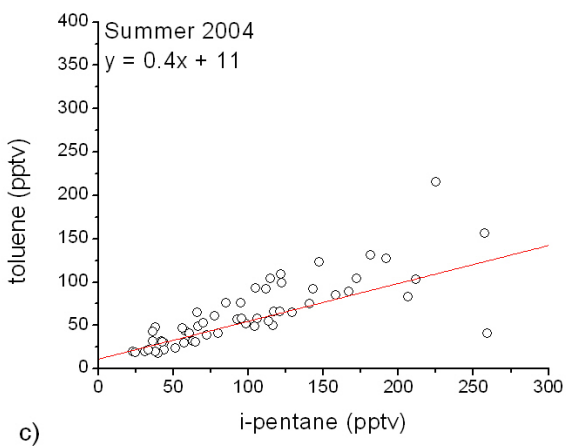

c)

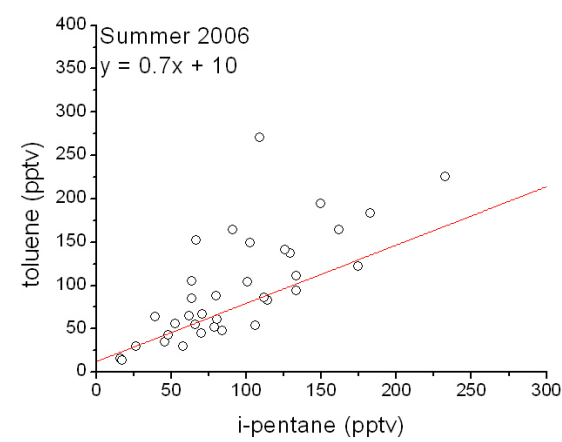

b)

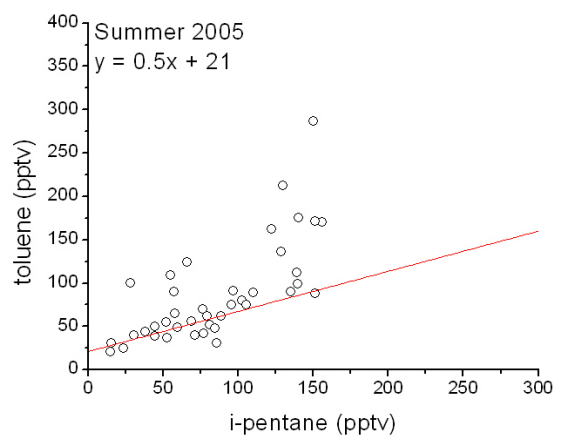

daily canister measurements June-August background toluene vs. i-pentane linear fit

Fig. 5. Toluene vs. i-pentane mixing ratios at Thompson Farm for June through August (a) 2004, (b) 2005, and (c) 2006. The background relationships were determined from the linear regressions of measurements below the median values for i-pentane (94, 79, and 81 pptv for 2004, 2005, and 2006, respectively) and toluene (54, 70, and $85 \mathrm{pptv}$ for 2004, 2005, and 2006, respectively) for each summer.

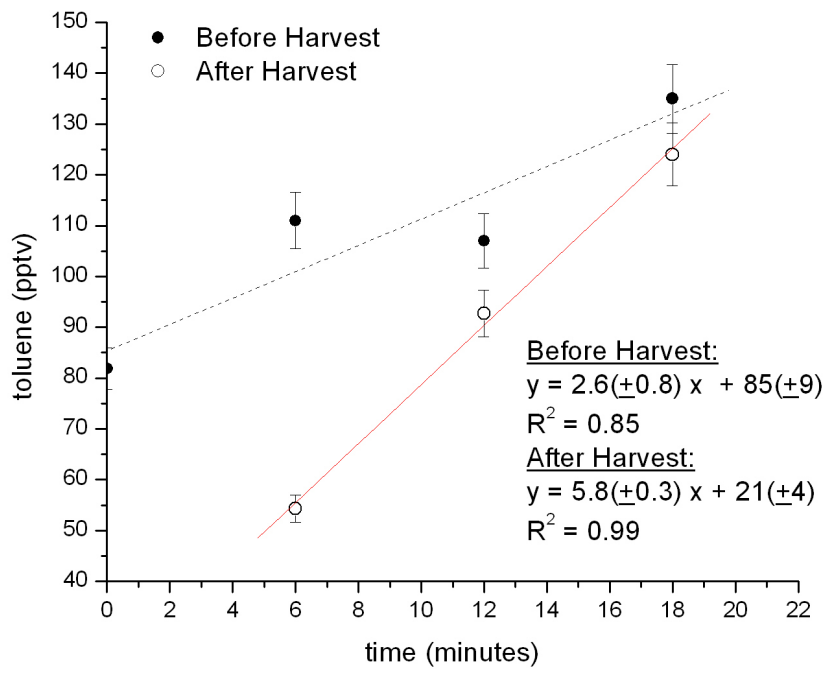

Fig. 6. 25 September 2007 static chamber measurements from Thompson Farm of alfalfa toluene production before and after harvesting. Error bars represent the measurement uncertainty of the GC system.

the higher slope associated with the background toluene and i-pentane relationship that year (Fig. 5c). Unfortunately, there are no current toluene flux measurements from corn,
Table 2. Vegetation toluene net flux rates from static and dynamic enclosure measurements. The loblolly pine net flux rate listed is the diurnally integrated flux rate from the 2 day sampling period. Flux errors were calculated as described in Sect. 2.2 and 2.3.

\begin{tabular}{lll}
\hline & $\begin{array}{r}\text { Toluene flux } \\
\text { nmol m }\end{array}$ & \\
& $\mathrm{d}^{2}$ \\
\hline 9/25/07: Alfalfa before harvest & $70 \pm 60$ & 0.62 \\
9/25/07: Alfalfa immediately after harvest & $200 \pm 10$ & 0.99 \\
10/5/07: Alfalfa 2 weeks after harvest & $80 \pm 50$ & 0.31 \\
6/4-6/6/05: Loblolly Pine & $500 \pm 300$ & \\
\hline
\end{tabular}

the major crop planted at Thompson Farm in 2004 and 2005. Should future measurements prove that corn is indeed a toluene source, these emissions may have also influenced the scatter of elevated toluene observed in the background toluene and i-pentane relationship for 2005 (Fig. 5b).

It should also be noted that the initial measurements of toluene flux rates from alfalfa presented in Table 2 were made at the end of September and beginning of October and emissions during the growing season could be significantly higher. For example, toluene fluxes measured from loblolly pine in North Carolina exhibited a strong temperature dependence (Fig. 7a) that, if applicable to alfalfa, indicate a substantial increase in flux rates during warmer seasons. 


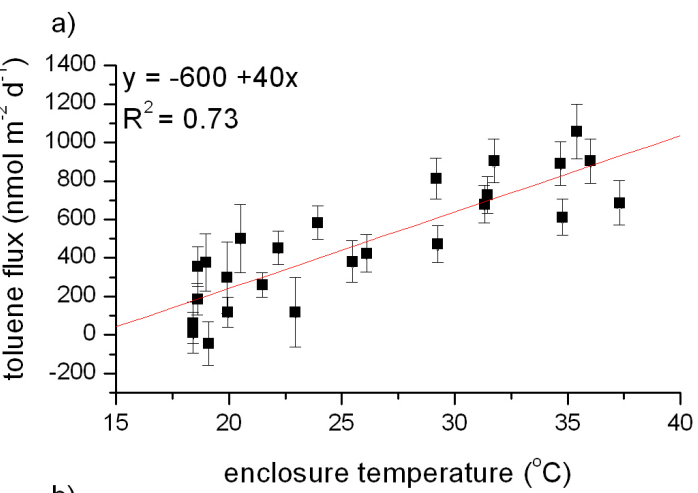

b)

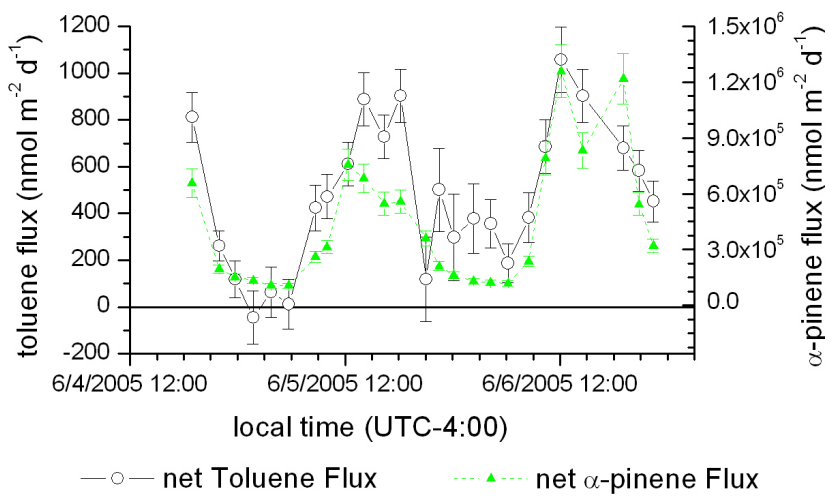

Fig. 7. June 2005 dynamic branch enclosure measurements from Duke Forest in Chapel Hill, North Carolina of loblolly pine net toluene flux with a) net toluene flux vs. temperature and (b) the time series of net toluene and $\alpha$-pinene flux. Original fluxes were calculated as $\mathrm{nmol} \mathrm{m}^{-2}$ leaf area $\mathrm{d}^{-1}$ and converted to $\mathrm{nmol} \mathrm{m}^{-2}$ ground area $\mathrm{d}^{-1}$ by multiplying by the average leaf area index (LAI) at the Duke Forest sampling site for June $2005,7 \mathrm{~m}^{2}$ leaf area $1 \mathrm{~m}^{-2}$ ground area. Error bars represent the individual flux error propagated from the uncertainty of measurements used in flux calculation

Assuming alfalfa emissions follow the loblolly pine temperature relationship, the average $9^{\circ} \mathrm{C}$ temperature difference between July and late September (2004-2007) at Thompson Farm would result in a summertime flux increase of approximately $360 \mathrm{nmol} \mathrm{m}^{-2} \mathrm{~d}^{-1}$ (or a total flux rate of approximately $430 \mathrm{nmol} \mathrm{m}^{-2} \mathrm{~d}^{-1}$ for unharvested alfalfa and $560 \mathrm{nmol} \mathrm{m}^{-2} \mathrm{~d}^{-1}$ after harvesting). Therefore, further study is warranted to quantify the temperature dependence of alfalfa flux and subsequently its seasonal cycle.

Our enclosure measurements of loblolly pine in North Carolina suggested comparable toluene flux magnitudes and diurnal emission patterns as those of Scots pines ( $\mathrm{Pi}$ nus sylvestris) sampled in Germany (Heiden et al., 1999). Loblolly pines also exhibited similar emission patterns between toluene and monoterpenes (Fig. 7b) that were consistent with correlations observed by Heiden et al. (1999) and suggest that biogenic toluene emission may be widespread for evergreen trees.
In contrast, negligible toluene production was evident in branch enclosure measurements of sweet gum ( $\mathrm{Liq}$ uidambar styraciflua), a deciduous tree species found in North Carolina. Furthermore, springtime emissions from local coniferous trees could explain the early toluene increase in May 2006 (Fig. 4). PTR-MS measurements of toluene and monoterpenes at Thompson Farm were more strongly correlated during the first two weeks of May $\left(r^{2}=0.82\right)$ than at any other time during that year (January-April $2006 r^{2}=0.31$, 14 May-August 2006, $r^{2}=0.47$, SeptemberDecember $r^{2}=0.41$ ). This is also consistent with observations by Heiden et al. (1999) that toluene emissions from Scots pine were highest in spring.

In addition to the crops and trees surrounding Thompson Farm, local industry could also influence ambient toluene mixing ratios. According to the EPA's Toxic Release Inventory, there were two industrial facilities that released approximately $11000 \mathrm{~kg}$ of toluene in 2005 located within a $20 \mathrm{~km}$ radius of Thompson Farm to the north and south (US Environmental Protection Agency, 2007). A wind direction analysis of measurements at Thompson Farm from June to August, when the seasonal enhancement was at its peak, revealed no distinct relationship between toluene and wind direction. With a lifetime on the order of days, the toluene lifetime is long enough for it to be dispersed and well-mixed with ambient air obscuring a directional relationship. However, an estimate of the daily ambient mixing ratio increase attributable to these local industrial emissions can be made by calculating the daily emission rate into the $20 \mathrm{~km}$ radius circle surrounding Thompson Farm (assuming a planetary boundary layer height of $1 \mathrm{~km}$ (Mao and Talbot, 2004b; Sive et al., 2007)). This rough approximation indicates that industrial emissions increase ambient toluene at Thompson Farm by $7 \mathrm{pptv} \mathrm{d}^{-1}$. While significant, this value is still much less than warm season toluene enhancements (approximately 2050 pptv as estimated in Sect. 3). Moreover, industrial emissions cannot produce the seasonal toluene patterns observed as the facilities are in operation year round presumably with little seasonality in their source strength. All of this evidence together rules out local industry as the major source responsible for the summertime toluene enhancements.

\section{Estimates of source contributions to Thompson Farm summer toluene enhancements}

In this section, the contributions to ambient summer toluene mixing ratios at Thompson Farm were quantified on a daily basis from the seasonal toluene sources, fuel evaporation and biogenic emissions (Table 3). Recognizing that there are assumptions associated with the calculations presented, these estimates provide an informative first estimate of the potential impact each toluene source could have on the seasonal enhancements observed. 
Table 3. Estimates of warm season toluene source contributions and summer mean toluene enhancement over the 2004-2006 springtime minimum mean ( $42 \pm 3$ pptv) at Thompson Farm. The errors given were propagated from the standard errors associated with the slopes and means used in calculation.

\begin{tabular}{ccccc}
\hline Year & $\begin{array}{c}\text { Toluene from } \\
\left(\mathrm{pptv} \mathrm{d}^{-1}\right)\end{array}$ & $\begin{array}{c}\text { Toluene from Crop } \\
\text { Plant Emissions } \\
\left(\mathrm{pptv} \mathrm{d}^{-1}\right)\end{array}$ & $\begin{array}{c}\text { Toluene from Pine } \\
\text { Tree Emissions } \\
\left(\mathrm{pptv} \mathrm{d}^{-1}\right)\end{array}$ & $\begin{array}{c}\text { Summer Toluene } \\
\text { Enhancement } \\
\left(\mathrm{pptv} \mathrm{d}^{-1}\right)\end{array}$ \\
\hline 2004 & $22 \pm 7$ & $5 \pm 0.3$ & $12 \pm 7$ & $21 \pm 6$ \\
2005 & $16 \pm 6$ & $5 \pm 0.3$ & $12 \pm 7$ & $43 \pm 9$ \\
2006 & $30 \pm 10$ & $5 \pm 0.3$ & $12 \pm 7$ & $50 \pm 10$ \\
\hline
\end{tabular}

\subsection{Fuel evaporation}

Contribution to the ambient toluene level from increased fuel evaporation was estimated by multiplying the slope of the background toluene-to-i-pentane relationship (given in Fig. 5a, b, and c) by the summertime i-pentane enhancements. It was assumed that the contribution from fuel evaporation to the ambient i-pentane level was minimal in winter and spring based on its temperature dependence. Therefore, we considered the minimum i-pentane mixing ratios from April and May (51 \pm 4 pptv, 2004-2006 mean) to be a background level, and the summertime i-pentane enhancement was estimated by subtracting this background value from the June-August i-pentane mean.

The fuel evaporation contribution for June-August 2004 $(22 \pm 7$ pptv) is consistent with the summer toluene enhancement above the springtime minimum for that year ( $21 \pm 6$ pptv) and reflects the dominant fuel evaporation source influence indicated in the toluene versus i-pentane scatter plot for summer 2004 (Fig. 5a). In contrast, the estimates of toluene fuel evaporation contributions for summer 2005 and 2006 (16 \pm 6 and $30 \pm 10$ pptv, respectively) cannot fully account for the toluene enhancements above springtime minimum in those years ( $43 \pm 9$ and $50 \pm 10$ pptv), further reinforcing the conclusion that additional toluene sources had important influences on the seasonal enhancements in those years. The 2006 summer fuel evaporation estimate may also include additional toluene source influences as the higher slope used to calculate the estimate reflected greater scatter in the toluene versus i-pentane background relationship in that year (Fig. 5c).

\subsection{Biogenic}

The potential toluene contributions from the crop plants and trees surrounding Thompson Farm were estimated by dividing the measured enclosure flux rates presented in Table 2 by a boundary layer height of $1 \mathrm{~km}$ (Mao and Talbot, 2004b; Sive et al., 2007). It should be noted that corn, rather than alfalfa, was planted at Thompson Farm in 2004 and 2005. Since corn has not been sampled for toluene emissions yet, the crop plant emission estimates presented for those years are based on the alfalfa toluene flux rates. Additionally, it was assumed that the diurnally integrated flux rates measured from loblolly pine in North Carolina are comparable to toluene emissions from the New England coniferous species surrounding Thompson Farm. The resulting estimates of biogenic toluene emissions $\left(5 \pm 0.3\right.$ and $12 \pm 7 \mathrm{pptv} \mathrm{d}^{-1}$ for crops and coniferous trees, respectively) are on the same order of magnitude as industrial $\left(7 \mathrm{pptv} \mathrm{d}^{-1}\right)$ and fuel evaporation emission (16-30 pptv d ${ }^{-1}$ ) estimates. Should there be a temperature dependence of toluene emission from alfalfa and corn resembling the one presented in Fig. 7a, local vegetation could make summer contributions to the seasonal toluene enhancements at Thompson Farm greater by a factor of 3 .

However, the apparent agreement noted in Sect. 5.1 between fuel evaporation estimates and summer toluene enhancements in 2004 suggest that biogenic emissions were overestimated for that summer. Significantly lower monoterpene levels in summer 2004 further indicate that regional biogenic emissions were reduced compared to the other two years (summer means from PTR-MS measurements $=310 \pm 6,452 \pm 2$, and $355 \pm 2$ pptv for 2004, 2005, and 2006, respectively. Means from all three years significantly different, independent means t-test: $\mathrm{p}<0.001$, SPSS v.15.0.1.1). Lower biogenic flux rates could reflect the cool, cloudy conditions that generally prevailed in the summer of 2004 as both the mean July-August temperature and the $\mathrm{J}_{\mathrm{NO} 2}$ photolysis rate measured at Thompson Farm were significantly lower than in 2005 and 2006 (mean temperature $=19.4 \pm 0.1,20.8 \pm 0.1$, and $20.7 \pm 0.1^{\circ} \mathrm{C}$ and mean $\mathrm{J}_{\mathrm{NO}_{2}}=0.00229 \pm 0.00005,0.00272 \pm 0.00006$, and $0.00287 \pm 0.00006 \mathrm{~s}^{-1}$ for summer 2004, 2005, and 2006, respectively, independent means t-test: $p<0.001$, SPSS v.15.0.1.1). In contrast, the high monoterpene levels observed during summer 2005 suggest that tree and/or crop toluene emissions may have been underestimated for that year. If this were the case, it could explain why the combined biogenic and fuel evaporation estimates ( $33 \pm 9$ pptv) were less than the observed summer toluene enhancement in 2005 (43 \pm 9 pptv). 
Table 4. Biogenic and anthropogenic toluene emission estimates for New England.

\begin{tabular}{|c|c|c|}
\hline \multirow[b]{2}{*}{ Toluene Source } & \multicolumn{2}{|c|}{ Emissions $\left(\mathrm{Mg} \mathrm{d}^{-1}\right)$} \\
\hline & $\begin{array}{c}\text { New England } \\
\text { (CT, RI, MA, NH, VT, ME) }\end{array}$ & $\begin{array}{l}\text { Northern New England } \\
\text { (NH, VT, ME only) }\end{array}$ \\
\hline Crop Emissions & 0.07 & 0.05 \\
\hline Forest Emissions & 6 & 5 \\
\hline On-road Mobile Source & 42 & 15 \\
\hline Non-road Mobile Source & 32 & 18 \\
\hline Non-point Mobile Source & 13 & 5 \\
\hline Point Source & 5 & 0.5 \\
\hline Total Anthropogenic & 92 & 39 \\
\hline
\end{tabular}

The combined emission estimates for summer 2006 (fuel evaporation + biogenic $=50 \pm 10$ pptv) were actually in good agreement with the observed summer toluene enhancement that year $(50 \pm 10 \mathrm{pptv})$. However, the crop emissions estimates presented in Table 3 may have been underestimated for that summer as the alfalfa toluene fluxes during the height of the growing season are expected to be greater than the late September flux rates used in our calculations. It should be noted that the higher slope (Fig. 5c) used to calculate the fuel evaporation emission estimate in 2006 indicated the influence of an additional toluene source on the background toluene and i-pentane relationship and an underestimate in biogenic emissions may have been balanced by overestimate of fuel evaporative emissions.

These initial estimates indicate the need for a more comprehensive study of the seasonal cycle and environmental controls of toluene fluxes from crops and trees to fully explain the interannual variability in vegetative toluene emissions suggested here. However, our measurements indicate the significant impact this unexpected source might have on toluene variability in rural areas.

\section{Comparison of biogenic and anthropogenic toluene emissions in New England}

Extrapolating the toluene flux rates measured from alfalfa and loblolly pines (Table 2) to estimated forest and cultivated land areas for New England (Agricultural Statistics Board, 2006; US Department of Agriculture Forest Service, 2006) also allows an initial comparison of the contribution of potential biogenic and anthropogenic emissions (US Environmental Protection Agency, 2002) to the regional ambient levels of toluene. Three assumptions were made in this comparison. First, the toluene flux rates measured from North Carolina loblolly pine are comparable to toluene emissions from the mixed coniferous-hardwood forests throughout New England (Department of Agriculture Forest Service, 2006). Second, the late September toluene flux rates measured from alfalfa immediately after harvesting are rep- resentative of emissions throughout the growing season for all crop types. Third, the seasonality in anthropogenic emission rates (including on-road, non-road, point, and non-point sources) reported for each state is negligible.

The estimated daily emission rates of toluene from crops, forests, and anthropogenic sources are presented in Table 4 for all New England states (i.e., Connecticut, Rhode Island, Massachusetts, New Hampshire, Vermont and Maine) as well as the more rural states of northern New England alone (New Hampshire, Vermont, and Maine). It was estimated that biogenic emissions of toluene in New England (6 and $0.07 \mathrm{Mg} \mathrm{d}^{-1}$ for forest and crop emissions) represent as much as $7 \%$ of total anthropogenic emissions $\left(92 \mathrm{Mg} \mathrm{d}^{-1}\right)$ with forest emissions on the same order of magnitude as industrial point source emissions $\left(5 \mathrm{Mgd}^{-1}\right)$. The northern states of New Hampshire, Vermont and Maine encompass the largest areas of forest and crop land in New England and therefore experience the most influence from biogenic sources. As anthropogenic emissions are also significantly less in these rural states, biogenic toluene emission rates are as much as $13 \%$ of total daily anthropogenic emissions in northern New England (39 $\mathrm{Mg} \mathrm{d}^{-1}$ ). These extrapolations further indicate the significant influence that biogenic emissions can have on toluene mixing ratios in rural New England and point to the need for more comprehensive studies of toluene emissions from vegetation.

\section{Conclusions}

The summertime enhancements in toluene mixing ratios evident in long-term daily measurements at Thompson Farm are driven by a combination of fuel evaporation emissions coupled with seasonal changes in RFG toluene content and biogenic emissions. Toluene releases from local industrial processes are also likely to impact ambient mixing ratios at the site but these emissions occur year-round and are unlikely to produce seasonal enhancements. Similar patterns of spring increases and summer correlations between i-pentane and toluene indicate that fuel evaporation emissions were the major influence on summer toluene enhancements in 2004. 
However, estimates of biogenic emissions from coniferous trees and crops were also significant and could not be fully dismissed, particularly in 2005 and 2006. The evidence of crop emission influences on seasonal toluene enhancements was strongest in 2006 when alfalfa was first planted in the Thompson Farm fields. Static chamber enclosure measurements revealed significantly increased toluene emissions from alfalfa after harvest. These flux measurements were made late in September and further studies are necessary to characterize the variability of toluene emissions from alfalfa and other vegetation more fully throughout the growing season. Extrapolations of the initial toluene flux measurements from pine and alfalfa to the forested and cultivated land areas of northern New England indicate that daily biogenic emission rates could be as much as $13 \%$ of total anthropogenic daily emission rates in rural areas further emphasizing the need for more comprehensive studies of toluene emissions from vegetation.

Acknowledgements. Financial support for this work was provided through the Office of Oceanic and Atmospheric Research at the National Oceanic and Atmospheric Administration under grants \#NA05OAR4601080 and \#NA06OAR4600189, and the US EPASTAR program through grant ${ }^{\#} \mathrm{RD}-8314540$. Research at the Duke FACE site was also supported by the Office of Science (BER), US Department of Energy, Grant No. DE-FG02-95ER62083. A special thanks to K. Allain, T. Finnigan-Allen, A. Csakai, P. Beckman, and S. Wadsworth at UNH.

Edited by: J. Rinne

\section{References}

Agricultural Statistics Board: Acreage, National Agricultural Statistics Service, US Department of Agriculture, Cr Pr 2-5 (606), 2006.

Cheng, L., Fu, L., Angle, R. P., and Sandhu, H. S.: Seasonal variations of volatile organic compounds in Edmonton, Alberta, Atmos. Environ., 31, 239-246, 1997.

deGouw, J. A., Middlebrook, A. M., Warneke, C., Goldan, P. D., Kuster, W. C., Roberts, J. M., Fehsenfeld, F. C., Worsnop, D. R., Canagaratna, M. R., Pszenny, A. A. P., Keene, W. C., Marchewka, M., Bertman, S. B., and Bates, T. S.: Budget of organic carbon in a polluted atmosphere: results from the New England Air Quality Study in 2002, J. Geophys. Res., 110, D16305, doi:10.1029/2004JD005623, 2005.

Dewulf, J. and Van Langenhove, H.: Analytical techniques for the determination and measurement data of 7 chlorinated $\mathrm{C} 1$ - and C2-hydrocarbons and 6 monocyclic aromatic hydrocarbons in remote air masses: an overview, Atmos. Environ., 31, 3291-3307, 1997.

Draxler, R. R. and Rolph, G. D.: HYSPLIT (HYbrid Single-Particle Lagrangian Integrated Trajectory) Model access via NOAA ARL READY Website (http://www.arl.noaa.gov/ready/hysplit4.html), 15 August 2008, 2003.

FACTS-1 LAI-2000 Leaf Area Index Measurements: http://face. env.duke.edu/products.cfm, access date: 15 June 2007, 2006.

Gary, J. H. and Handwerk, G. E.: Petroleum Refining: Technology and Economics, Marcel Dekker, Inc., New York, 8-13, 2001.
Gelencser, A., Siszler, K., and Hlavay, J.: Toluene-benzene concentration ratio as a tool for characterizing the distance from vehicular emission sources, Environ. Sci. Technol., 31, 2869-2872, 1997.

Goldhaber, S., Wolf, S., and Laney, M.: Health Effects Notebook for Hazardous Air Pollutants, US Environmental Protection Agency, http://www.epa.gov/ttn/atw/hlthef/hapindex.html, 1995.

Griffin, R. J., Johnson, C. A., Talbot, R. W., Mao, H., Russo, R. S., Zhou, Y., and Sive, B. C.: Quantification of ozone formation metrics at Thompson Farm during the New England Air Quality Study (NEAQS) 2002, J. Geophys. Res., 109, D24302, doi:10.1029/2004JD005344, 2004.

Heiden, A. C., Kobel, K., Komenda, M., Koppmann, R., Shao, M., and Wildt, J.: Toluene emissions from plants, Geophys. Res. Lett., 26, 1283-1286, 1999.

Lobert, J. M., Scharffe, D. H., Hao, W. M., and Crutzen, P. J.: Importance of biomass burning in the atmospheric budgets of nitrogen-containing gases, Nature, 346, 552-554, 1990.

Lough, G. C., Schauer, J. J., Lonneman, W. A., and Allen, M. K.: Summer and winter nonmethane hydrocarbon emissions from on-road motor vehicles in the midwestern United States, J. Air Waste Manage., 55, 629-646, 2005.

Mao, H. and Talbot, R.: $\mathrm{O}_{3}$ and $\mathrm{CO}$ in New England: Temporal variations and relationships, J. Geophys. Res., 109, D21304, doi:10.1029/2004JD004913, 2004a.

Mao, H., and Talbot, R.: Role of meteorological processes in two New England ozone episodes during summer 2001, J. Geophys. Res., 109, D20305, doi:10.1029/2004JD004850, 2004b.

Mao, H., Talbot, R., Nielsen, C., and Sive, B.: Controls on methanol and acetone in marine and continental atmospheres, Geophys. Res. Lett., 33, L02803, doi:10.1029/2005GL024810, 2006.

McClenny, W. A., Daughtrey, E. H., Adams, J. R., Oliver, K. D., and Kronmiller, K. G.: Volatile organic compound concentration patterns at the New Hendersonville monitoring site in the 1995 Southern Oxidants Study in the Nashville, Tennessee, area, J. Geophys. Res., 103, 22509-22518, 1998.

Na, K. and Kim, Y. P.: Seasonal characteristics of ambient volatile organic compounds in Seoul, Korea, Atmos. Environ., 35, 26032614, 2001.

Ng, N. L., Kroll, J. H., Chan, A. W. H., Chhabra, P. S., Flagan, R. C., and Seinfeld, J. H.: Secondary organic aerosol formation from m-xylene, toluene, and benzene, Atmos. Chem. Phys., 7, 3909-3922, 2007, http://www.atmos-chem-phys.net/7/3909/2007/.

Romanow, S.: Fuel Trends Report: Gasoline 1995-2005, Compliance and Innovative Strategies Division, Office of Transportation and Air Quality, US Environmental Protection Agency, EPA420R-08-002, 2008.

Russo, R. S., Zhou, Y., White, M. L., Talbot, R., and Sive, B. C., et al.: Long Term Measurements of Nonmethane Hydrocarbons and Halocarbons in New Hampshire (2004-2008): Seasonal Variations and Regional Sources, Atmos. Chem. Phys. Discuss., in preparation, 2008.

Schauer, J. J., Fraser, M. P., Cass, G. R., and Simoneit, B. R. T.: Source reconciliation of atmospheric gas phase and particle phase pollutants during a severe photochemical smog episode, Environ. Sci. Tech., 36, 3806-3814, 2002.

Singh, H. B., Salas, L. J., Cantrell, B. K., and Redmond, R. M.: Distribution of aromatic hydrocarbons in the ambient air, Atmos. 
Environ, 19, 1911-1919, 1985.

Singh, H. B. and Zimmerman, P. B.: Atmospheric distribution and sources of nonmethane hydrocarbons, in: Gaseous Pollutants: Characterization and Cycling, edited by: Nriagu, J. O., John Wiley \& Sons, Inc., New York, 177-235, 1992.

Sive, B. C., Zhou, Y., Troop, D., Wang, Y., Little, W. C., Wingenter, O. W., Russo, R. S., Varner, R. K., and Talbot, R.: Development of a cryogen-free concentration system for measurements of volatile organic compounds, Anal. Chem., 77, 6989-6998, 2005.

Sive, B. C., Varner, R. K., Mao, H., Blake, D. R., Wingenter, O. W., and Talbot, R.: A large terrestrial source of methyl iodide, Geophys. Res. Lett, 34, L17808, doi:10.1029/2007GL030528, 2007.

Smyth, S., Bradshaw, J., Sandholm, S., Liu, S. C., McKeen, S. A., Gregory, G. L., Anderson, B. E., Talbot, R., Blake, D., Rowland, F. S., Browell, E., Fenn, M., Merrill, J. T., Bachmeier, S., Sachse, G., Collins, J., Thornton, D. C., Davis, D. D., and Singh, H. B.: Comparison of free tropospheric western Pacific air mass classification schemes for the PEM-West A experiment, J. Geophys. Res., 101, 1743-1762, 1996.

Talbot, R., Mao, H., and Sive, B.: Diurnal characteristics of surface level $\mathrm{O}_{3}$ and other important trace gases in New England, J. Geophys. Res., 110, D09307, doi:10:1029/2004JD005449, 2005.

Taylor, J. R.: An introduction to error analysis, in: the study of uncertainties in physical measurements, Books in Physics, edited by: Commins, E. D., University Science Books, Sausalito, CA, 270 pp., 1982.

US Department of Agriculture Forest Service, Forest Inventory Data Online: http://199.128.173.26/fido/mastf/index.html, 15 August 2008, 2006.

US Environmental Protection Agency, National Emissions Inventory: http://www.epa.gov/ttn/chief/net/2002inventory.html, 15 August 2008, 2002.

US Environmental Protection Agency, Toxic Release Inventory (TRI) Explorer Online Database: http://www.epa.gov/ triexplorer/,15 June 2007, 2005.
Varner, R. K., Crill, P. M., and Talbot, R. W.: Wetlands: a potentially significant source of atmospheric methyl bromide and methyl chloride, Geophys. Res. Lett., 26, 2433-2436, 1999.

Wang, Y., Jacob, D. J., and Logan, J. A.: Global simulation of tropospheric O3-NOx-hydrocarbon chemistry: 3. Origin of tropospheric ozone and effects of nonmethane hydrocarbons, J. Geophys. Res., 103, 10757-10767, 1998.

Warneke, C., De Gouw, J. A., Stohl, A., Cooper, O. R., Goldan, P., Kuster, W., Holloway, J., Williams, E. J., Lerner, B. M., Mckeen, S. A., Trainer, M., Fehsenfeld, F. C., Atlas, E. L., Donnelly, S. G., Stroud, V., Lueb, A., and Kato, S.: Biomass burning and anthropogenic sources of CO over New England in the summer 2004, J. Geophys. Res., 111, D23S15, doi:10.1029/2005JD006878, 2006.

Warneke, C., McKeen, S. A., Gouw, J. A. D., Goldan, P. D., Kuster, W. C., Holloway, J. S., Williams, E. J., Lerner, B. M., Parrish, D. D., Trainer, M., Fehsenfeld, F. C., Kato, S., Atlas, E. L., Baker, A., and Blake, D. R.: Determination of urban volatile organic compound emission ratios and comparison with an emissions database, J. Geophys. Res., 112, D104S107, doi:110.1029/2006JD007930, 2007.

White, M. L., Russo, R. S., Zhou, Y., Mao, H., Varner, R. K., Ambrose, J., Veres, P., Wingenter, O. W., Haase, K., Stutz, J., Talbot, R., and Sive, B. C.: Volatile Organic Compounds in Northern New England Marine and Continental Environments during the ICARTT 2004 Campaign, J. Geophys. Res., 113, D08S90, doi:10.1029/2007JD009161, 2008.

Zhou, Y., Varner, R. K., Russo, R. S., Wingenter, O. W., Haase, K. B., Talbot, R., and Sive, B. C.: Coastal water source of short-lived halocarbons in New England, J. Geophys. Res., 110, D21302, doi:10.1029/2004JD005603, 2005.

Zhou, Y., Mao, H., Russo, R. S., Blake, D. R., Wingenter, O. W., Haase, K., Ambrose, J. L., Varner, R. K., Talbot, R., and Sive, B.: Bromoform and dibromomethane measurements in the seacoast region of New Hampshire, 2002-2004, J. Geophys. Res., 113, D08305, doi:10.1029/2007JD009103, 2008. 